\title{
Inhibition of renal cell carcinoma angiogenesis and growth by antisense oligonucleotides targeting vascular endothelial growth factor
}

\author{
W Shi' and DW Siemann ${ }^{*, 1,2}$ \\ 'Department of Pharmacology and Experimental Therapeutics, University of Florida, Box 100267, I600 SW Archer Road, Gainesville, FL 32610, USA; \\ ${ }^{2}$ Department of Radiation Oncology, Shands Cancer Centre, University of Florida, Box 100385, 2000 SW Archer Road, Gainesville, FL 326I0, USA
}

Angiogenesis is critical for growth and metastatic spread of solid tumours. It is tightly controlled by specific regulatory factors. Vascular endothelial growth factor has been implicated as the key factor in tumour angiogenesis. In the present studies we evaluated the effects of blocking vascular endothelial growth factor production by antisense phosphorothioate oligodeoxynucleotides on the growth and angiogenic activity of a pre-clinical model of renal cell carcinoma (Caki-I). In vitro studies showed that treating Caki-I cells with antisense phosphorothioate oligodeoxynucleotides directed against vascular endothelial growth factor mRNA led to a reduction in expressed vascular endothelial growth factor levels sufficient to impair the proliferation and migration of co-cultured endothelial cells. The observed effects were antisense sequence specific, dose dependent, and could be achieved at a low, non-toxic concentration of phosphorothioate oligodeoxynucleotides. When vascular endothelial growth factor antisense treated Caki-I cells were injected into nude mice and evaluated for their angiogenic potential, the number of vessels initiated were approximately half that induced by untreated Caki-I cells. To test the anti-tumour efficacy of vascular endothelial growth factor antisense, phosphorothioate oligodeoxynucleotides were administrated to nude mice bearing macroscopic Caki-I xenografts. The results showed that the systemic administration of two doses of vascular endothelial growth factor antisense phosphorothioate oligodeoxynucleotides given I and 4 days after the tumours reached a size of $\sim 200 \mathrm{~mm}^{3}$ significantly increased the time for tumours to grow to $1000 \mathrm{~mm}^{3}$.

British Journal of Cancer (2002) 87, 119 - 126. doi:10.1038/sj.bjc.66004I6 www.bjcancer.com

(c) 2002 Cancer Research UK

Keywords: renal cell carcinoma; vascular endothelial growth factor; angiogenesis; antisense oligodeoxynucleotides

Angiogenesis, a complex multi-step process involving the formation of new blood vessels from pre-existing ones, is tightly regulated by both positive and negative regulatory factors (Risau, 1997). These regulators, which included pro-angiogenic factors such as basic fibroblast growth factor (bFGF) (Wang and Becker, 1997), angiogenin (Gho and Chae, 1997) and vascular endothelial growth factor (VEGF) (Kim et al, 1993; Asano et al, 1995; Borgstrom et al, 1996; Cheng et al, 1996; Saleh et al, 1996), as well as angiostatic peptides such as endostatin (O'Reilly et al, 1997; Perletti et al, 2000), angiostatin (O'Reilly et al, 1994a,b) and thrombospondin (Folkman and Shing, 1992; Folkman, 1995) are potential targets for anti-angiogenic therapy of solid tumours (Folkman, 1971; Bicknell and Harris, 1992; Harris et al, 1994; Denekamp, 1999).

Vascular endothelial growth factor is an endothelial cell specific mitogen, secreted as a $45 \mathrm{kDa}$ homo dimer protein. There are five human isoforms derived from alternative splicing (VEGF 121, 145, 165, 189, 206) (Houck et al, 1991). VEGF121 and VEGF165 are the only soluble isoforms and also the most abundant, with VEGF165 being the most powerful stimulator of endothelial cell proliferation (Soker et al, 1997). VEGF165 is commonly expressed in a wide variety of human and animal tumours (Hanahan and Folkman,

*Correspondence: DW Siemann; E-mail: siemadw@ufl.edu Received 18 February 2002; revised 22 April 2002; accepted 23 April 2002
1996) and has been shown to induce angiogenesis both in vitro and in vivo (Leung et al, 1989; Plate et al, 1992). It is currently believed that this diffusible molecule is probably a key mediator of tumour angiogenesis (Ferrara, 1999). Indeed, the expression of VEGF has been related to fundamental features of tumours, such as growth rate (Kim et al, 1993), microvessel density (Toi et al, 1994) and vascular architecture (Drake, 1999) as well as the development of tumour metastasis (Weidner et al, 1991). A correlation between VEGF expression and survival has been noted in some cancer patients (Maeda et al, 1996; Gasparini et al, 1997).

In light of its role in tumour angiogenesis, VEGF may be an attractive target for anti-angiogenic therapeutic interventions applied to the treatment of cancer. Renal cell carcinoma (RCC) may be an excellent site to investigate VEGF targeted anti-angiogenic therapies. RCC is the most common malignancy of the kidney in adults and accounts for about $2 \%$ of all adult malignancies (McLaughlin and Lipworth, 2000). Histopathologic evaluations of RCC reveal it to be a highly vascularised neoplasm demonstrating clear evidence of abundant angiogenesis and abnormal blood vessel development (Yoshino et al, 2000). Not surprisingly, several studies have pointed to an important role for pro-angiogenic growth factors in RCC. VEGF has been shown to be expressed in renal cell carcinoma tissues and renal cell carcinoma cell lines (Sato et al, 1994; Wang and Becker, 1997; Paradis et al, 2000). Serum levels of VEGF often are elevated in RCC patients (Sato et al, 1999) and VEGF mRNA levels in renal cell carcinoma have been 
reported to be higher than those found in surrounding normal tissues (Takahashi et al, 1994; Berger et al, 1995). In addition, elevated serum/urine VEGF levels have been shown to associated with malignant progression and poor treatment outcome (Sato et al, 1994; Baccala et al, 1998; Tomisawa et al, 1999; Ishizuka et al, 2000; Jacobsen et al, 2000). Taken together, these findings suggest that VEGF is one of the important factors involved in the angiogenesis of RCC.

In the present study we evaluated the anti-angiogenic and antitumour effects of VEGF antisense phosphorothioate oligodeoxynucleotides (PS-ODNs) in a pre-clinical model of human RCC (Caki-1).

\section{MATERIALS AND METHODS}

\section{Cell culture}

The clear cell RCC cell line Caki-1 was a gift from Dr Susan Knox (Stanford University). Caki-1 cells were grown in Dulbecco's modified minimum essential medium (DMEM Invitrogen, Grand Island, NY, USA) supplemented with $10 \%$ foetal bovine serum (FBS, Invitrogen, Grand Island, NY, USA), 1\% penicillin-streptomycin (Invitrogen, Grand Island, NY, USA) and 1\% $200 \mathrm{mmol} \mathrm{l}^{-1} \mathrm{~L}$ glutamine (Invitrogen, Grand Island, NY, USA). The mouse heart endothelial cell line (MHE) was a gift from Dr Robert Auerbach (University of Wisconsin). MHE cells were grown in DMEM supplemented with $10 \%$ heat inactivated foetal bovine serum, $1 \%$ penicillin-streptomycin and $1 \% \quad 200 \mathrm{mmol} \mathrm{l}^{-1}$ L-glutamine. Human microvascular endothelial cell from the lung (HMVEC-L) cells were obtained from Clonetics (San Diego, CA, USA) HMVEC-L cells were grown in EBM-2-MV (Clonetics, San Diego, CA, USA) supplemented with $5 \%$ FBS.

\section{Caki-1 xenografts}

Female nude mice (NCR, nu/nu), age $6-8$ weeks were maintained under specific-pathogen-free conditions (University of Florida Health Science Centre) with food and water supplied ad libitum. Animals were inoculated subcutaneously in a single flank with $5 \times 10^{6}$ tumour cells. When the tumours reached a size $\sim 200$ $\mathrm{mm}^{3}$, animals were randomly assigned to the different treatment groups. All animal experiments have been carried out with ethical committee approval. The ethical guidelines that were followed meet the standards required by the Cancer Research UK guidelines (Workman et al, 1998).

\section{Phosphorothioate oligodeoxynucleotides (PS-ODNs)}

Antisense and control PS-ODNs (20-mers) were custom synthesised by Geno Mechanix (Alachua, FL, USA). PS-ODNs V515 was complementary to $5^{\prime}$ UTR just up-stream of the translation start site (AUG codon) of VEGF mRNA: 5'-CTC ACC CGT CCA TGA GCC CG-3'. A scramble sequence: $5^{\prime}$-CAC CCT GCT CAC CGC ATG GC-3'; sense sequence: 5'-CGG GCT CAT GGA CGG GTG AG-3' and an inverted sequence: $5^{\prime}$-GCC CGA GTA CCT GCC CAC TC-3', were used as PS-ODNs controls. All PS-ODNs were suspended in sterile and endotoxin free water at a concentration of $1 \mathrm{mM}$, aliquoted and stored at $-20^{\circ} \mathrm{C}$.

\section{DOTAP : DOPE liposome preparation}

Cationic liposomes were prepared using the method described by Tang and Hughes (1999). Briefly, cationic lipid 1,2-dioleoyloxy-3(trimethylammonium) propane (DOTAP) was dissolved in chloroform and mixed with a helper lipid 1,2-dioleoyl-3-snphosphatidylethanolamine (DOPE) (Avanti Polar-Lipids, Alabaster, AL, USA) at a molar ratio of $1: 1$. The mixture was evaporated to dryness in a round-bottomed flask using a rotary evaporator at room temperature. The resulting lipid film was dried by nitrogen for an additional $10 \mathrm{~min}$ to evaporate any residual chloroform. The lipid film was re-suspended in sterile water to a final concentration of $1 \mathrm{mg} \mathrm{ml}^{-1}$ based on the weight of cationic lipid. The resultant mixtures were shaken in a water bath at $35^{\circ} \mathrm{C}$ for $30 \mathrm{~min}$. The suspensions were then sonicated using a Sonic Dismembrator (Fisher Scientific, Pittsburgh, PA, USA) for 1 min at room temperature to form homogenised liposomes. The particle-size distribution of liposomes was measured using a NICOMP 380 ZLS instrument (Santa Barbara, CA, USA). The average particle diameter was $144.0 \pm 77.0 \mathrm{~nm}$. Liposomes were stored at $4^{\circ} \mathrm{C}$ and used within 3 months.

\section{VEGF enzyme immunoassay}

Caki-1 cells $\left(1 \times 10^{5}\right)$ were set in $60 \mathrm{~mm}$ dishes and allowed to attach overnight. The medium then was removed and replaced with PS-ODNs in serum free medium with liposome (DOTAP:DOPE) and incubated for $5 \mathrm{~h}$. Fresh medium containing 10\% FBS then was added. After $24 \mathrm{~h}$ of incubation the VEGF concentration was determined in the medium using a human VEGF immunoassay kit ( $\mathrm{R} \& \mathrm{D}$ Systems, Minneapolis, MN, USA).

\section{VEGF relative quantitative $\mathrm{RT}-\mathrm{PCR}$}

Caki-1 cells were set at $3 \times 10^{5}$ in $100 \mathrm{~mm}$ dishes and allowed to attach overnight. The cells were then treated with $1 \mu \mathrm{M}$ VEGF antisense or control PS-ODNs as described. Twenty-four hours later the cells were collected and the total RNA was isolated using a RNeasy Mini Kit (Qiagen, Valencia, CA, USA) and RNA concentrations were determined by UV spectrophotometry. A $2 \mu \mathrm{g}$ total RNA sample was used to reverse synthesize cDNA using Superscript II reverse transcriptase (Invitrogen, Grand Island, NY, USA). A $2.5 \mu$ l aliquot of the reverse transcriptase reaction product then was used for the PCR reaction. VEGF PCR reactions were carried out with a VEGF gene specific relative RT-PCR Kit (Ambion, Austin, TX, USA). The PCR reactions were run 22 cycles (denature $94^{\circ} \mathrm{C} 30 \mathrm{~s}$, anneal $60^{\circ} \mathrm{C} 60 \mathrm{~s}$, extension $72^{\circ} \mathrm{C} 60 \mathrm{~s}$ ) in a DNA Engine 200 (MJ research, Waltham, MA, USA). PCR products then were run in $2 \%$ agrose gel and stained by ethidium bromide. The gels were visualised and analysed (Gel Doc 2000 gel documentation system, Bio-Rad, Hercules, CA, USA).

\section{Co-culture assay}

Transwell (Corning, Corning, NY, USA) 6-well dishes with a membrane pore size of $0.4 \mu \mathrm{M}$ were used. Caki-1 cells were seeded at $5 \times 10^{4}$ in the transwell inserts and MHE or HMVEC-L cells were plated at $5 \times 10^{4}$ per well in the 6 -well dishes and allowed to attach overnight. The Caki-1 cell medium was then replaced with serum free medium containing $1 \mu \mathrm{M}$ V515 PS-ODNs or control PS-ODNs liposome complexes (DOTAP:DOPE). After $5 \mathrm{~h}$ of treatment, medium containing $10 \%$ heat inactivated FBS was added to yield a final FBS concentration of $2.5 \%$. The transwells containing treated Caki-1 cells were assembled with 6-well dished containing MHE and HMVEC-L cells and incubated at $37^{\circ} \mathrm{C}$ for $48 \mathrm{~h}$ at which time the numbers of MHE or HMVEC-L cells were determined by haemocytometer count.

\section{Migration assay}

Caki-1 cells were set at $1 \times 10^{5}$ per well in 24 -well dishes and allowed to attach overnight. The Caki-1 cells then were treated with $1 \mu \mathrm{M}$ control or V515 PS-ODNs for $24 \mathrm{~h}$. HTS FluoroBlok inserts (Becton Dickinson, Franklin Lakes, NJ, USA) with a pore size of $8.0 \mu \mathrm{m}$ were assembled into the 24-well dish with the Caki-1 cells. MHE or HMVEC-L cells were grown in T-150 flasks to about $80 \%$ confluence. The endothelial cells were stained in 
medium containing $10 \mu \mathrm{g} \mathrm{ml}^{-1}$ Di-I (Molecular Probes, Eugene, OR, USA) for $24 \mathrm{~h}$, washed four times with PBS, collected, added into the FluoroBlok inserts $\left(5 \times 10^{4}\right.$ MHE or HMVEC-L) and incubated for $24 \mathrm{~h}$. The number of migrated endothelial cells then were determined by direct measurement of the fluorescence in the bottom well using a CytoFluor 4000 plate reader (Perceptive BioSystems, St. Paul, MN, USA).

\section{Intradermal angiogenesis assay}

Caki-1 cells $\left(5 \times 10^{4}\right)$ were inoculated intradermally in a volume of $10 \mu \mathrm{l}$ at four sites on the ventral surface of nude mice. One drop of $0.4 \%$ trypan blue was added to the cell suspension, which making it lightly coloured, simplifying subsequent location of the sites of injection. Three days later the mice were killed, the skin carefully separated from the underlying muscle and the number of vessels counted using a dissecting microscope (Sidky and Auerbach, 1976). Scoring of all of the reaction areas was carried out at the same magnification $(\times 5)$ and only vessels readily detected at this magnification were counted. The sites of injection, recognised by local swelling and blue staining, were exposed by carefully removing fat or other tissue covering the area. All vessels that touched the edge of the tumour inoculates were counted. All the animals in the experiments were pre-coded and vessel counts in each animal were scored twice. The resultant data points for each treatment group were pooled for statistical analysis (Wilcoxon rank sum test).

\section{PS-ODNs up-take in tumour}

FITC labelled control PS-ODNs were mixed with DOTAP:DOPE in $200 \mu \mathrm{l} 5 \%$ dextrose and injected into Caki-1 xenograft bearing mice via the tail vein at a dose of $20 \mathrm{mg} \mathrm{kg}^{-1}$. Three hours later, the mice were killed by $\mathrm{CO}_{2}$ asphyxiation, the tumours removed, frozen in liquid nitrogen and $20 \mu \mathrm{m}$ sections were cut. The sections were photographed using a Zeiss Axioplan 2 Florescence Microscope (Zeiss, Thornwood, NY, USA) within 3 days.

\section{VEGF Western blot}

VEGF antisense PS-ODNs V515 was injected tail vein at a dose of $10 \mathrm{mg} \mathrm{kg}^{-1}$. At various times after injection $(24,48$ and $72 \mathrm{~h}$ ), the mice were killed, the tumours excised and frozen in liquid nitrogen. The tumours were then homogenised (Dounce tissue grinder, Wheaton, Millville, NJ, USA) and the homogenates were lysed on ice for $30 \mathrm{~min}$ with $1 \mathrm{ml}$ of hypotonic buffer $(20 \mathrm{mM}$ Tris- $\mathrm{HCl}, \mathrm{pH} 6.8,1 \mathrm{mM} \mathrm{MgCl}_{2}, 2 \mathrm{mM}$ EGTA, 0.5\% Nonidet P40, $2 \mathrm{mM}$ Phenylmethanesulphonyl fluoride (PMSF), $200 \mathrm{u} \mathrm{ml}^{-1}$ Approtinin, $2 \mu \mathrm{g} \mathrm{ml}^{-1}$ leupetin) (Giannakakou et al, 1998) per $0.1 \mathrm{~g}$ tissue. Following a brief but vigorous vortex the samples were centrifuged at 14000 r.p.m. for $10 \mathrm{~min}$ at $4^{\circ} \mathrm{C}$. A $30 \mu \mathrm{l}$ aloquot of each sample was mixed with $10 \mu \mathrm{l} 4 \times$ SDS-PAGE sample buffer $(0.3 \mathrm{M}$ Tris- $\mathrm{HCl}, \mathrm{pH} 6.8,45 \%$ glycerol, $20 \% \quad \beta$-mercaptoethanol, $9.2 \%$ SDS and $0.04 \mathrm{~g}$ per $100 \mathrm{ml}$ bromophenol blue) and heated at $100^{\circ} \mathrm{C}$ for $10 \mathrm{~min}$. Thirty $\mu \mathrm{l}$ of each sample was then analysed by SDS-PAGE on a $12 \%$ separating gel and $3 \%$ stacking gel. Following transfer, the membrane was immunoblotted using a VEGF primary antibody (Sigma, Saint Louis, MS, USA) 1:1000 diluted in antibody solution (3\% dry milk, $25 \mathrm{~mm}$ Tris, $\mathrm{pH} 7.5$, $0.5 \mathrm{M} \mathrm{NaCl}, 0.05 \%$ Tween 20 ) overnight at $4^{\circ} \mathrm{C}$. After washing, a secondary antibody labelled with horseradish peroxidase was applied and incubated at room temperature for $1 \mathrm{~h}$. Protein bands were visualised and densitometry was performed.

\section{Tumour growth delay assay}

Once the Caki-1 xenografts reached a size of $\sim 200 \mathrm{~mm}^{3}$, animals were assigned randomly to various treatment groups. V515 or control PS-ODNs were administrated via the tail vein with DOTAP:DOPE liposomes at a dose of $5 \mathrm{mg} \mathrm{kg}^{-1}$ or $10 \mathrm{mg} \mathrm{kg}$ on day 1 and day 4. Tumours were measured using callipers and volumes were approximated by the formula, volume $=1 / 6 \pi a \mathrm{~b}^{2}$, with $a$ and $b$ represent two perpendicular tumour diameters. The times for the tumours in the various treatment groups to grow from $200 \mathrm{~mm}^{3}$ to $1000 \mathrm{~mm}^{3}$ were recorded and compared (Wilcoxon rank sum test).

\section{RESULTS}

The ability to down-regulate VEGF expression by antisense PSODNs treatment in Caki-1 tumour cells was first evaluated in vitro. The results showed that after $24 \mathrm{~h}$ treatment with $1 \mu \mathrm{M}$ VEGF antisense PS-ODNs (V515) delivered by cationic liposome (DOTAP:DOPE), the medium VEGF level was significantly reduced to $\sim 35 \%$ that found in the control untreated group (from a normal of $850 \mathrm{pg} \mathrm{ml}^{-1} 10^{6}$ cells $^{-1}$ to $300 \mathrm{pg} \mathrm{ml}^{-1} 10^{6}$ cells $^{-1}$ ) (Figure 1). This effect was sequence, and target region specific. Treating Caki-1 cells with liposome vehicles (DOTAP: DOPE) or control scramble PS-ODNs did not affect VEGF levels. Similarly, treatment with sense or inverted sequence PS-ODNs failed to reduce VEGF expression. PS-ODNs treatment did not affect Caki-1 cell viability and proliferation. This repression of VEGF expression by V515 was dose dependent (Figure 2). For example, a $24 \mathrm{~h}$ treatment with $0.5 \mu \mathrm{M}$, reduced the medium VEGF level to $56 \%$ of control $(P<0.01)$ whereas a $1 \mu \mathrm{M}$ dose down-regulated the VEGF level to $22 \%$ of control $(P<0.05)$. VEGF mRNA levels in different PS-ODNs treatment groups also were determined (Figure 3 ). The results indicated a marked inhibition of VEGF mRNA after treatment with V515 which was absent in cells treated with scramble PS-ODNs.

Since the goal of VEGF antisense therapy is to inhibit cancer cell induced angiogenic signalling, experiments then were designed to evaluate the impact of reducing tumour cell expression of VFGF by antisense PS-ODNs treatment on endothelial cell growth and migration. Because the ultimate goal was to examine the efficacy of VEGF antisense treatment in a human tumour model grown in a mouse host, we evaluated the effect on both human (HMVEC-L) and mouse (MHE) endothelial cells. Transwell co-

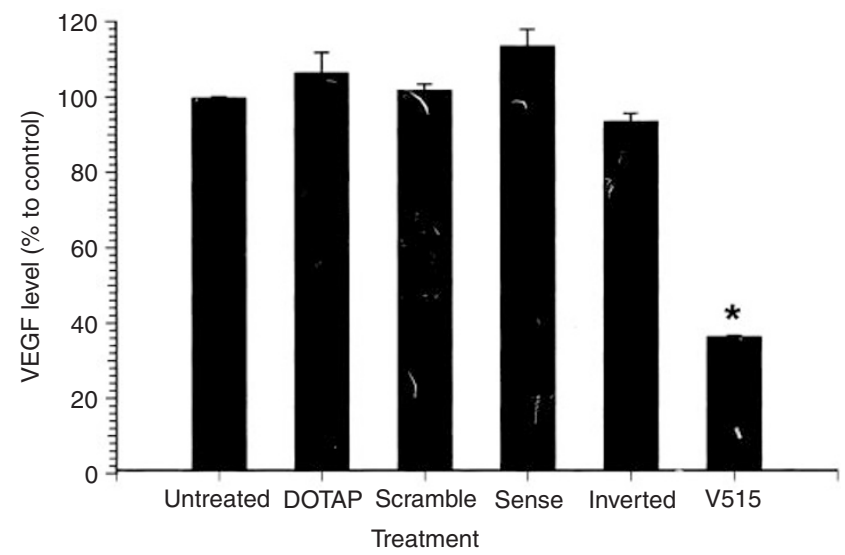

Figure I VEGF levels in culture medium of Caki-I tumour cells treated with different antisense PS-ODNs. The cells were either untreated (Untreated) or treated with delivery vehicle only (DOTAP), a I $\mu \mathrm{M}$ dose of control PS-ODNs sequences (Scramble, Sense and Inverted) or a I $\mu \mathrm{M}$ dose of antisense PS-ODNs targeted to a specific sequence of VEGF mRNA (V5।5). Each bar represents the mean + s.e. of three independent experiments. The star indicates a significant difference from the untreated or control treated groups ( $P<0.05$, student's $t$-test). The 100\% VEGF expression level of the untreated group corresponds to $\sim 850 \mathrm{pg} \mathrm{ml}^{-1} 10^{6}$ cells $^{-1}$. 


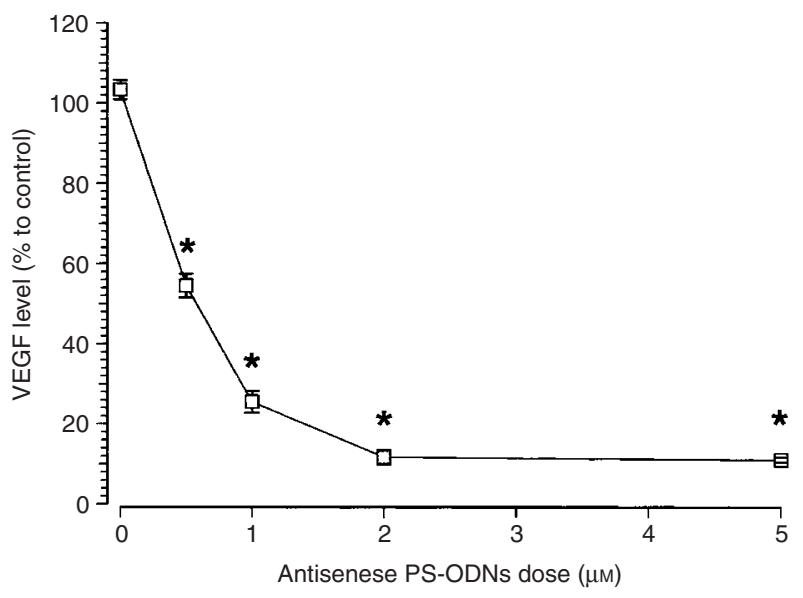

Figure 2 VEGF levels in the culture medium of Caki-I tumour cells treated with different doses $(0.5,1,2,5 \mu \mathrm{M})$ of VEGF antisense PS-ODNs ( $\mathrm{V} 5$ |5). The 0 dose group was treated with scramble control PS-ODNs $(5 \mu \mathrm{M})$. Each square represents the mean \pm s.e. of three independent experiments. The stars indicate significant differences from 0 dose $(P<0.05$, student's t-test)

A
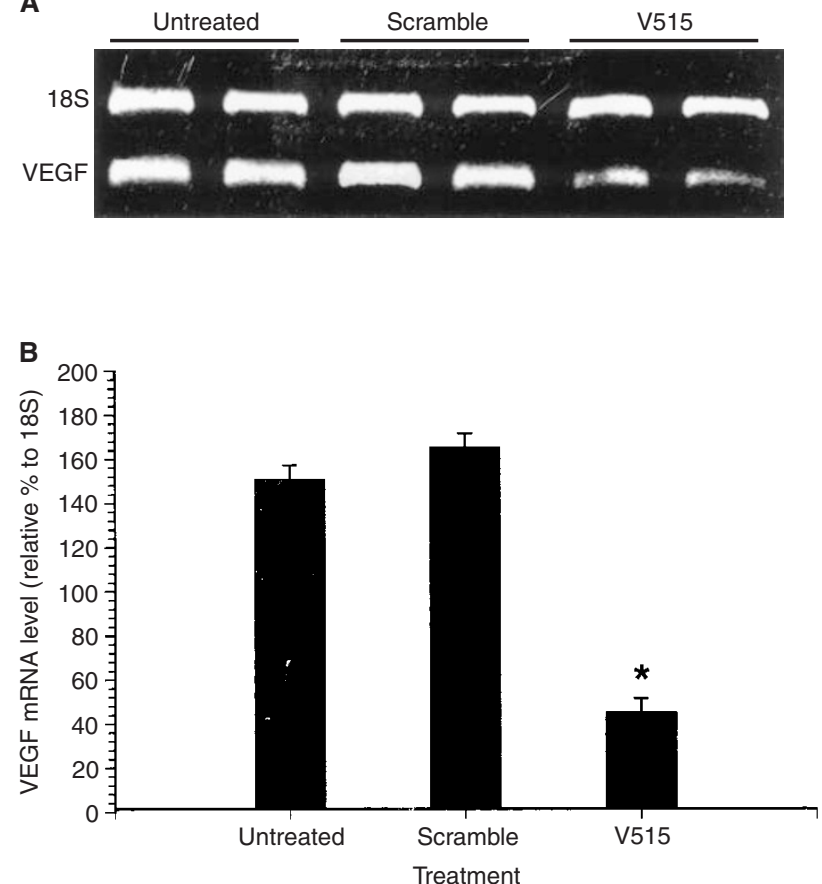

Figure 3 Message RNA levels in Caki-I cells which were either untreated or treated with a I $\mu \mathrm{M}$ dose of scramble control sequence or VEGF antisense PD-ODNs (V5I5). (A) Representative relative RT - PCR results, each group was performed in duplicate; I 8 s indicates the RT - PCR amplification band of $18 \mathrm{~s}$ ribosomal RNA. (B) Relative VEGF mRNA levels of Caki-I cells treated with different PS-ODNs. The values were obtained by dividing the densitometer reading of the VEGF band by that of the I8s band. Each bar is the mean \pm s.e. of three experiments. The star indicates a significant difference $(P<0.05$, student's $t$-test).

culture systems were used to mimic the in vivo paracrine interaction between tumour cells and endothelial cells. Caki-1 tumour cells were grown in transwells with $0.4 \mu \mathrm{m}$ membrane pores. These were chosen to allow the exchange of growth factors but without direct cell-cell interactions. The effects of pretreating Caki-1 tumour cells with VEGF antisense PS-ODNs on endothelial cell proliferation then were determined (Figure 4). The results showed that compared to untreated Caki-1 cells, Caki-1 cells pre-treated with V515 significantly inhibited both HMVEC-L and MHE cell proliferation. Once again, treating Caki-1 cells with a variety of control PS-ODNs had no effect on HMVEC-L or MHE cell growth.

To test whether a reduction in VEGF expression by tumour cells could affect endothelial cell migration, HMVEC-L or MHE cells were stained with $10 \mu \mathrm{g} \mathrm{ml}^{-1} \mathrm{Di}$-I for $24 \mathrm{~h}$ and added into Fluoroblok inserts placed into 24 well dishes containing Caki-1 tumour cells treated with either control or V515. The number of prelabelled endothelial cells which migrated through the $8 \mu \mathrm{m}$ pore size membranes in a $24 \mathrm{~h}$ period were quantified by determining the fluorescence intensity in the bottom well. The results showed (Figure 5) that $24 \mathrm{~h}$ after co-culturing the two cell populations $\sim 35 \%(P<0.05)$ and 27\% $(P<0.05)$ fewer MHE or HMVEC-L cells respectively migrated through the membrane in the presence of V515 treated Caki-1 cells compared to untreated or scramble control PS-ODNs treated Caki-1 cells.

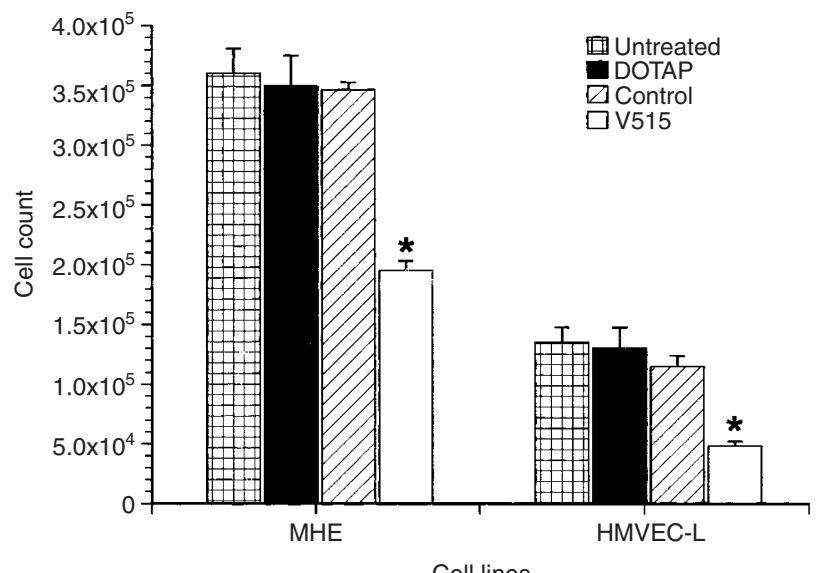

Figure 4 Effect of co-culturing Caki-I tumour cells on the growth of endothelial cells (MHE and HMVEC-L). Caki-I cells were untreated or pretreated with DOTAP liposome vehicle, I $\mu \mathrm{M}$ scramble control PS-ODNs or I $\mu \mathrm{M}$ V5I5 antisense PS-ODNs. Each bar represents the mean \pm s.e. of three independent experiments. Stars indicate significant difference $(P<0.05$, student's $t$-test) from the untreated group.

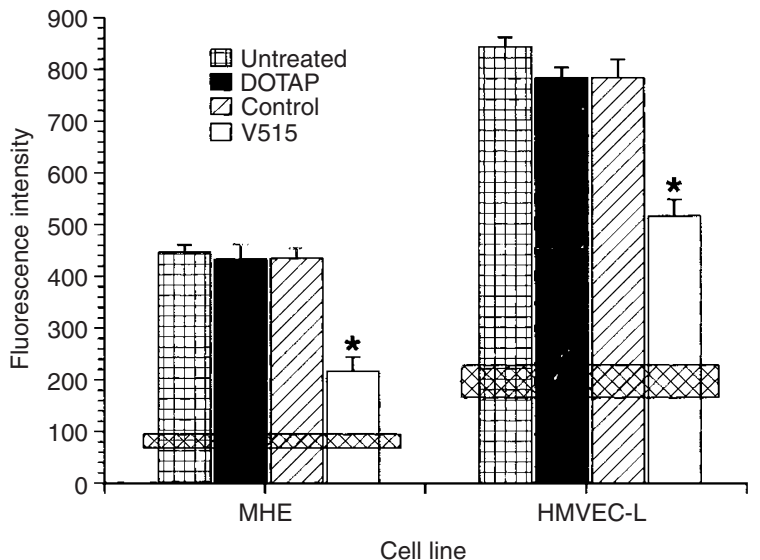

Figure 5 Impact of co-culturing Caki-I tumour cells on ability of MHE and HMVEC-L cells to migrate. Caki-I cells were untreated or pre-treated with DOTAP liposome vehicle, a I $\mu \mathrm{M}$ dose of scramble control or a I $\mu \mathrm{M}$ dose of V5 I 5 antisense PS-ODNs. Each bar represents the mean \pm s.e. of three experiments. The stars indicate a significant difference $(P<0.05$, student's $t$-test) from the untreated groups. The horizontal bars show the levels of spontaneous migration of endothelial cells cultured alone; the bar widths correspond to the mean values \pm I s.e. 
Although, the in vitro studies indicated that treating Caki-1 tumour cells with VEGF mRNA targeted antisense PS-ODNs down-regulated VEGF protein production sufficiently to affect the proliferation and migration of endothelial cells, it was important to demonstrate that such treatments also could affect Caki-1 cell induction of angiogenesis in vivo. To examine this possibility Caki-1 cells that had been treated with V515 or control PS-ODNs were injected intradermally and the number of vessels induced were counted 3 days later (Figure 6). While untreated Caki-1 cells and control PS-ODNs treated Caki-1 cells had very similar angiogenic potency in vivo (both groups induced $\sim 44-46$ new vessels in the assay period), the angiogenic potential of Caki-1 cells that had been pre-treated with V515 antisense PS-ODNs (V515) was found to be significantly impaired; only $\sim 25$ new blood vessels were observed.

To evaluate the tumour up-take of PS-ODNs delivered by cationic liposome (DOTAP:DOPE). FITC labelled PS-ODNs were mixed with cationic liposome DOTAP:DOPE in 5\% dextrose and were injected via the tail vein at a dose of $20 \mathrm{mg} \mathrm{kg}^{-1}$ into Caki-1 xenograft-bearing nude mice. Frozen sections prepared $3 \mathrm{~h}$ later showed the FITC labelled PS-ODNs to be efficiently delivered to the tumour (Figure 7). The heterogeneous PS-ODNs uptake likely reflects the inhomogeneous distribution of blood vessels in the tumour. To further confirm the antisense effect of V515 in vivo, tumour samples were collected at various times after V515 injection. Western blot analysis of these samples showed significant reductions in VEGF levels at 24,48 and $72 \mathrm{~h}$, with the maximum depression occurring at $48 \mathrm{~h}$ after treatment (Figure 8). These findings clearly indicate the delivery of VEGF antisense to the tumour would result in a reduction in VEGF expression levels.

Subsequent experiments were undertaken to determine the antitumour efficacy of V515 antisense PS-ODNs when delivered systemically by examining the effect of such treatments on Caki1 tumour growth. Caki-1 xenografts-bearing mice were treated with two doses of VEGF antisense PS-ODNs V515 (5 or $10 \mathrm{mg} \mathrm{kg}^{-1}$ ) 1 and 4 days after the tumours reached a size of $\sim 200 \mathrm{~mm}^{3}$. The time for the tumours to grow from $200 \mathrm{~mm}^{3}$ to $1000 \mathrm{~mm}^{3}$ then was recorded (Figure 9). The data showed that the median time for the tumours to grow to five times the starting

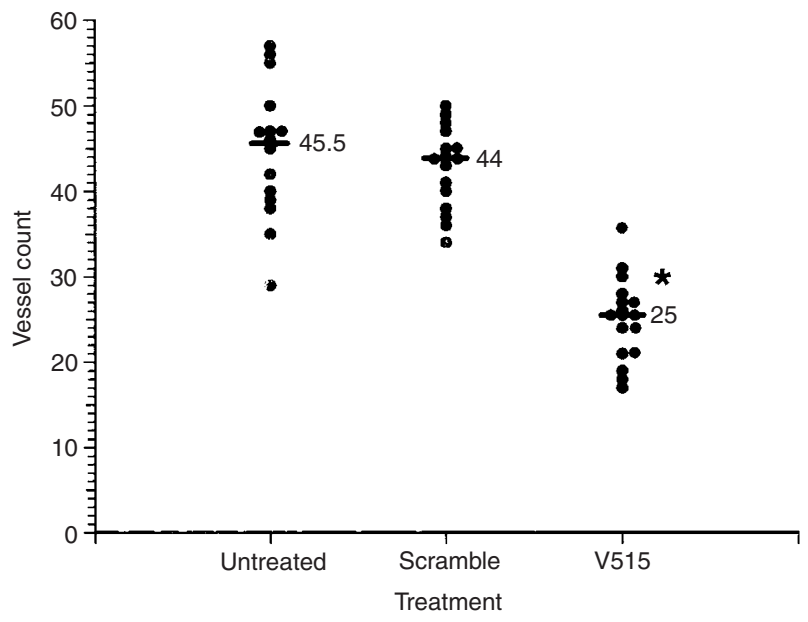

Figure 6 Number of blood vessels induced 3 days after injecting $5 \times 10^{4}$ Caki- I cells intradermally in nude mice. Caki- I cells were either untreated or pre-treated with a I $\mu$ M dose of PS-ODNs for $3 \mathrm{~h}$. The Scramble group refers to cells pre-treated with scramble control PS-ODNs, whereas the V5I5 group represents Caki-I cells pre-treated with VEGF antisense PSODNs (V5 I5). Each datum point represents one injection site, the bars show the median of 16 sites in each group. The V5 15 treated group was significantly different from the untreated or scramble control groups $(P<0.05$, Wilcoxon rank sum test).

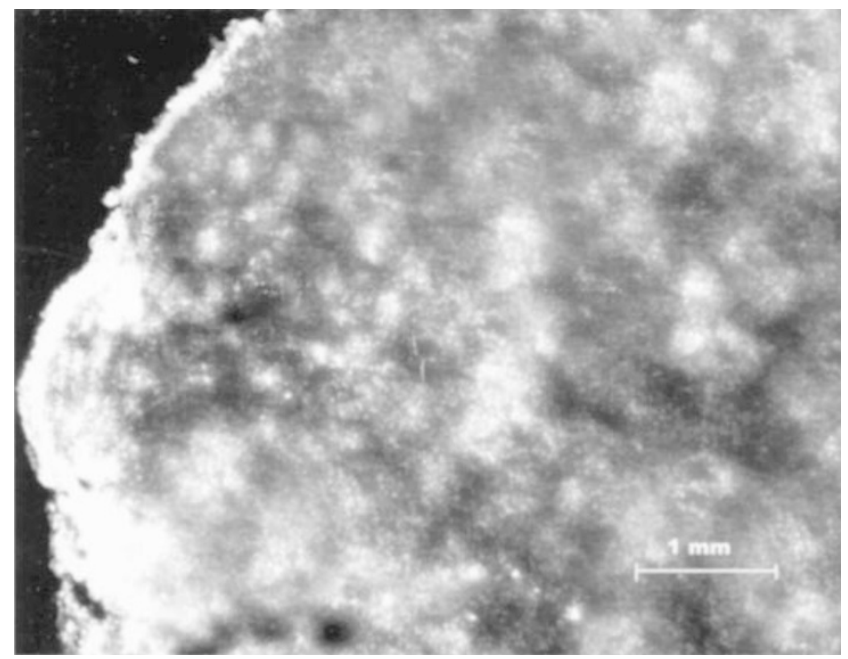

Figure 7 Uptake and distribution of FITC-labelled PS-ODNs in Caki-I xenografts determined $3 \mathrm{~h}$ after an i.v. injection of a $20 \mathrm{mg} \mathrm{kg}^{-1}$ dose. PS-ODNs were prepared with DOTAP:DOPE. Sections were $20 \mu \mathrm{m}$.
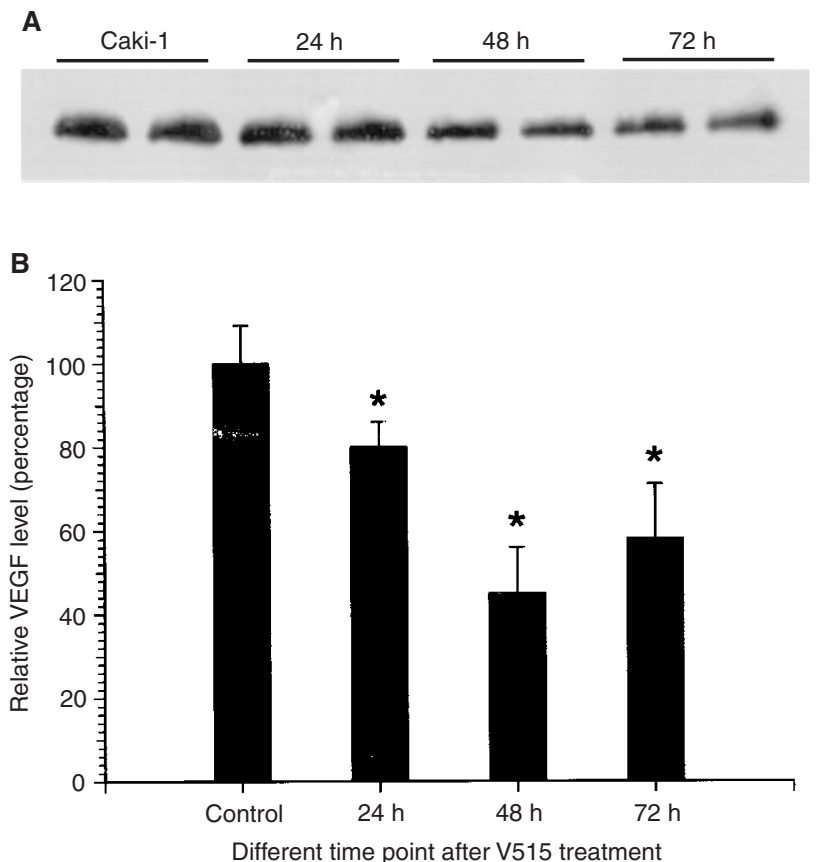

Figure 8 VEGF protein levels in Caki-I tumours at different time points after treatment of $10 \mathrm{mg} \mathrm{kg}^{-1}$ VEGF antisense PD-ODNs (V5 I5). (A) Representative VEGF Western blot results, showing two tumour samples of each group; (B) Relative VEGF protein levels of Caki-I tumours treated VEGF antisense PD-ODNs (V5I5). Each bar is the mean \pm s.e. of six tumours. The star indicates a significant difference $(P<0.05$, student's $t$ test).

size was significantly prolonged in the V515 antisense PS-ODNs (V515) treated groups. Administrating two doses of $5 \mathrm{mg} \mathrm{kg}{ }^{-1}$ caused a growth delay of $\sim 5.5$ days $(P<0.05$, Wilcoxon rank sum test) while treatment with two $10 \mathrm{mg} \mathrm{kg}^{-1}$ doses led to a tumour growth delay of $\sim 8$ days. The latter treatment therefore resulted in an approximately doubled the response of the tumours compared to the tumours of untreated or scramble PS-ODNs treated mice. No toxicity of such antisense PS-ODNs treatment was observed. This included no significant weight loss, no abnormal movements or behaviour and no loose stools. 

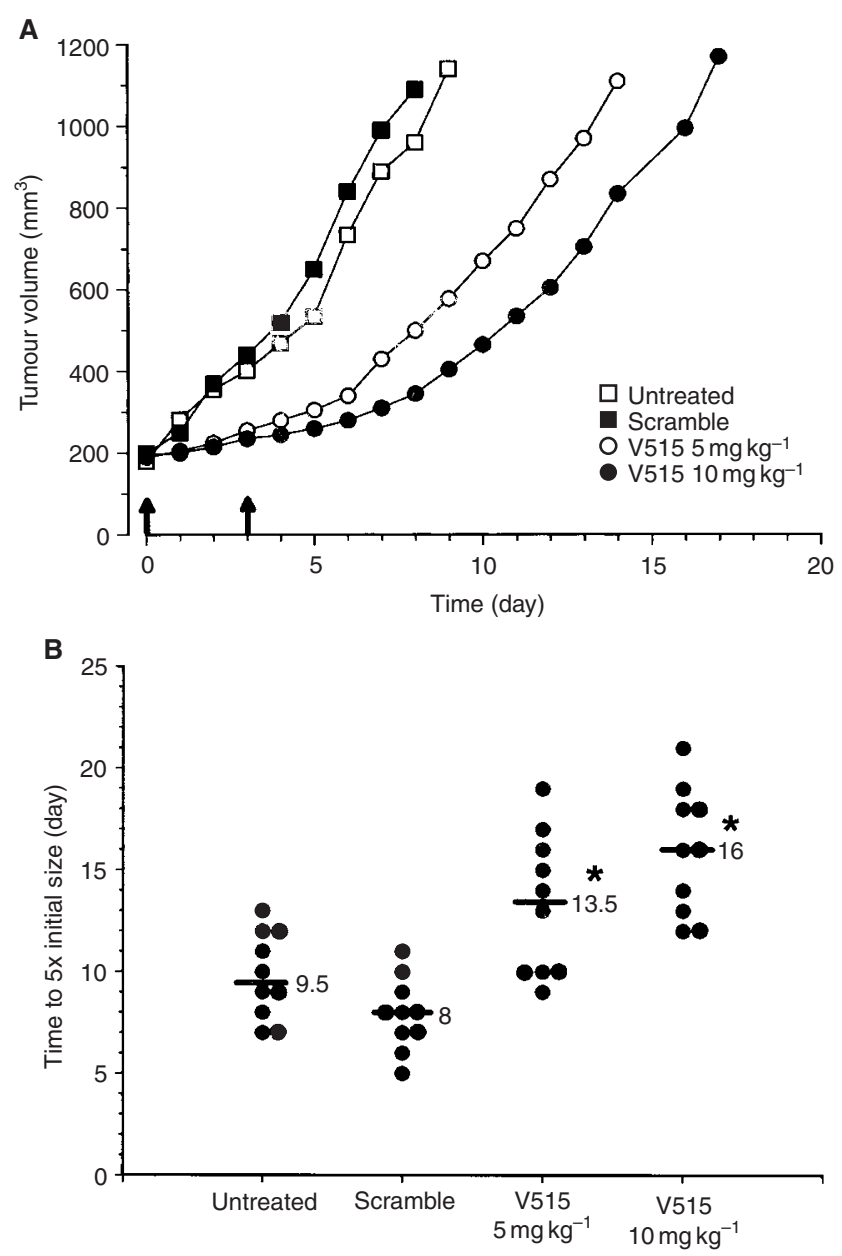

Treatment

Figure 9 (A) Growth of median RCC Caki-I tumours in nude mice treated systemically with antisense PS-ODNs against VEGF. Mice were untreated, treated with $10 \mathrm{mg} \mathrm{kg}^{-1}$ scramble PS-ODNs, $5 \mathrm{mg} \mathrm{kg}^{-1}$ VEGF antisense $\mathrm{V} 5 \mathrm{I} 5$, or $10 \mathrm{mg} \mathrm{kg}^{-}$VEGF antisense $\mathrm{V} 5 \mathrm{I} 5$ at the time indicated by arrows. Each group consisted of 10 animals. (B) Tumour response of Caki-I xenografts treated systemically with antisense PS-ODNs targeted to VEGF mRNA. Scramble control (Scramble) or VEGF antisense (V5 I5) PS-ODNs were administrated with cationic liposome (DOTAP:DOPE) via the tail vein I and 4 days after the tumours reached a size of $\sim 200$ $\mathrm{mm}^{3}$. Liposome administration alone had no effect on Caki-I tumour growth (data not shown). Each circle represents a single tumour; the bars show the response of the median tumour in each group of 10 mice. The stars indicate significant differences $(P<0.05$, Wilcoxon rank sum test) from the untreated and scramble control groups.

\section{DISCUSSION}

Anti-angiogenesis treatment strategies represent a new approach to cancer management. Given that solid tumours cannot progress effectively without the generation of new blood vessels, various tacks have been taken to interfere with tumour angiogenesis. One possible target which has received considerable attention is the pro-angiogenic factor VEGF. VEGF can induce endothelial cell proliferation and migration in vitro (Hanahan and Folkman, 1996; Soker et al, 1997) and angiogenesis in vivo (Leung et al, 1989; Plate et al, 1992). Its expression level has been associated with a variety of tumours and correlated to treatment outcome (Maeda et al, 1996; Gasparini et al, 1997). To date, attempts to abrogate the angiogenic activity of VEGF have focused on inactivating VEGF through the use of antibodies (Kim et al, 1993; Mordenti et al, 1999) and soluble receptors (Lin et al, 1998), inhi- biting VEGF receptor tyrosine kinases (Hennequin et al, 1999) or suppressing VEGF message (Ellis et al, 1996; Smyth et al, 1997; Nguyen et al, 1998). The latter relied on antisense oligonucleotides or antisense RNA (Eguchi et al, 1991; Mercola and Cohen, 1995; Phillips and Zhang, 2000) to modulate gene expression by disrupting RNA expression. While the inhibition of VEGF expression by vector mediated gene transfer of antisense RNA has been shown to lead to growth delays in several tumour models (Folkman and Shing, 1992; Belletti et al, 1999; Kang et al, 2000; Nakashima et $a l, 2000$ ), the only reports of in vivo efficacy when using VEGF antisense oligonucleotides occurred in VEGF dependent tumour models (Masood et al, 1997, 2001). In the present studies, we used a VEGF independent tumour model of RCC (VEGF-R negative) to evaluate the in vitro and in vivo efficacy of a different VEGF antisense PS-ODNs sequence (V515). Antisense oligodeoxynucleotide technology provides an approach for inhibiting gene expression with target specificity as a particular advantage (Stein and Cheng, 1993; Engelhard, 1998). Antisense oligonucleotides are easy to produce in large quantities which make them potentially more practical than antisense RNA vector delivery approaches.

In the present study, we investigated the anti-angiogenic and anti-tumour effects of VEGF antisense PS-ODNs in a VEGF independent tumour model of RCC. In vitro experiments showed that the inhibition of VEGF production in Caki-1 tumour cells by antisense PS-ODNs treatment significantly reduced the ability of cocultured endothelial cells to proliferate (Figure 4) and migrate (Figure 5). To minimise interference of other growth factors in the serum, these studies were carried out under reduced serum conditions. Importantly, suppressing tumour cell expression of VEGF message impaired angiogenic responses in both human and mouse endothelial cells. Subsequent in vivo studies demonstrated that treating Caki-1 tumour cells with VEGF antisense PS-ODNs significantly impaired their ability to elicit an angiogenic response when injected intradermally (Figure 6). These results not only support the role of VEGF as an important pro-angiogenic growth factor in Caki-1 cell induced angiogenesis, but also clearly suggest that inhibition of cancer cell VEGF expression may ultimately impact tumour growth. This belief was born out in experiments evaluating the in vivo anti-tumour efficacy of systemic administration of VEGF antisense PS-ODNs which showed that substantial tumour growth delays could be achieved with such treatment (Figure 9).

The results of this study indicate a key role for the VEGF signalling pathway in renal cell carcinoma angiogenesis. Treatment with VEGF antisense PS-ODNs to down regulate VEGF production was found to be effective at impairing the Caki-1 angiogenic signalling both in vitro and in vivo. Most importantly the systemic administration of VEGF antisense PS-ODNs to mice bearing macroscopic tumours resulted in significant inhibition of the growth of VEGF independent RCC tumour model. Taken together, these findings suggest that antisense PS-ODNs targeted to VEGF may have utility in the management of renal cell carcinoma either alone or in conjunction with conventional anti-cancer therapies.

\section{ACKNOWLEDGEMENTS}

This work was supported by USPNS grant CA89655. 


\section{REFERENCES}

Asano M, Yukita A, Matsumoto T, Kondo S, Suzuki H (1995) Inhibition of tumor growth and metastasis by an immunoneutralizing monoclonal antibody to human vascular endothelial growth factor/vascular permeability factor121. Cancer Res 55: 5296-5301

Baccala AA, Zhong H, Clift SM, Nelson WG, Marshall FF, Passe TJ, Gambill NB, Simons JW (1998) Serum vascular endothelial growth factor is a candidate biomarker of metastatic tumor response to ex vivo gene therapy of renal cell cancer. Urology 51: $327-332$

Belletti B, Ferraro P, Arra C, Baldassarre G, Bruni P, Staibano S, De Rosa G, Salvatore G, Fusco A, Persico MG, Viglietto G (1999) Modulation of in vivo growth of thyroid tumor-derived cell lines by sense and antisense vascular endothelial growth factor gene. Oncogene 18: 4860-4869

Berger DP, Herbstritt L, Dengler WA, Marme D, Mertelsmann R, Fiebig HH (1995) Vascular endothelial growth factor (VEGF) mRNA expression in human tumor models of different histologies. Ann Oncol 6: 817-825

Bicknell R, Harris AL (1992) Anticancer strategies involving the vasculature: vascular targeting and the inhibition of angiogenesis. Semin Cancer Bol 3: $399-407$

Borgstrom P, Hillan KJ, Sriramarao P, Ferrara N (1996) Complete inhibition of angiogenesis and growth of microtumors by anti-vascular endothelial growth factor neutralizing antibody: novel concepts of angiostatic therapy from intravital videomicroscopy. Cancer Res 56: 4032 - 4039

Cheng SY, Huang HJ, Nagane M, Ji XD, Wang D, Shih CC, Arap W, Huang CM, Cavenee WK (1996) Suppression of glioblastoma angiogenicity and tumorigenicity by inhibition of endogenous expression of vascular endothelial growth factor. Proc Natl Acad Sci USA 93: 8502-8507

Denekamp J (1999) The tumour microcirculation as a target in cancer therapy: a clearer perspective. Eur J Clin Invest 29: 733-736

Drake CJ LCD (1999) VEGF and vascular fusion: implications for normal and pathological vessels. J Histochem Cytochem 47: 1351-1356

Eguchi Y, Itoh T, Tomizawa J (1991) Antisense RNA. Annu Rev Biochem 60: $631-652$

Ellis LM, Liu W, Wilson M (1996) Down-regulation of vascular endothelial growth factor in human colon carcinoma cell lines by antisense transfection decreases endothelial cell proliferation. Surgery 120: $871-878$

Engelhard HH (1998) Antisense oligodeoxynucleotide technology: potential use for the treatment of malignant brain tumors. Cancer Control 5: $163-170$

Ferrara N (1999) Molecular and biological properties of vascular endothelial growth factor. J Mol Med 77: 527-543

Folkman J (1971) Tumor angiogenesis: therapeutic implications. $N$ Engl J Med 285: $1182-1186$

Folkman J (1995) Angiogenesis inhibitors generated by tumors. Mol Med 1: $120-122$

Folkman J, Shing Y (1992) Control of angiogenesis by heparin and other sulfated polysaccharides. Adv Exp Med Biol 313: 355-364

Gasparini G, Toi M, Gion M, Verderio P, Dittadi R, Hanatani M, Matsubara I, Vinante O, Bonoldi E, Boracchi P, Gatti C, Suzuki H, Tominaga T (1997) Prognostic significance of vascular endothelial growth factor protein in node-negative breast carcinoma. J Natl Cancer Inst 89: 139- 147

Giannakakou P, Villalba L, Li H, Poruchynsky M, Fojo T (1998) Combinations of paclitaxel and vinblastine and their effects on tubulin polymerization and cellular cytotoxicity: characterization of a synergistic schedule. Int J Cancer 5:(Suppl 75(1)): 57-63

Gho YS, Chae CB (1997) Anti-angiogenin activity of the peptides complementary to the receptor- binding site of angiogenin. J Biol Chem 272: 24294-24299

Hanahan D, Folkman J (1996) Patterns and emerging mechanisms of the angiogenic switch during tumorigenesis. Cell 86: $353-364$

Harris AL, Fox S, Bicknell R, Leek R, Relf M, LeJeune S, Kaklamanis L (1994) Gene therapy through signal transduction pathways and angiogenic growth factors as therapeutic targets in breast cancer. Cancer 74: 1021-1025

Hennequin LF, Thomas AP, Johnstone C, Stokes ES, Plé PA, Lohmann JJ, Ogilvie DJ, Dukes M, Wedge SR, Curwen JO, Kendrew J, Lambert-van der Brempt C (1999) Design and structure-activity relationship of a new class of potent VEGF receptor tyrosine kinase inhibitors. J Med Chem 42: $5369-5389$
Houck KA, Ferrara N, Winer J, Cachianes G, Li B, Leung DW (1991) The vascular endothelial growth factor family: identification of a fourth molecular species and characterization of alternative splicing of RNA. Mol Endocrinol 5: $1806-1814$

Ishizuka T, Hayashi T, Nakazawa H, Ito F, Nitta K, Horita S, Uchida K, Nihei $\mathrm{H}$, Toma H (2000) Serum vascular endothelial growth factor is a candidate biomarker of renal cell carcinoma in hemodialysis patients. Nephron 84: $83-84$

Jacobsen J, Rasmuson T, Grankvist K, Ljungberg B (2000) Vascular endothelial growth factor as prognostic factor in renal cell carcinoma. J Urol 163: $343-347$

Kang MA, Kim KY, Seol JY, Kim KC, Nam MJ (2000) The growth inhibition of hepatoma by gene transfer of antisense vascular endothelial growth factor. J Gene Med 2: 289-296

Kim KJ, Li B, Winer J, Armanini M, Gillett N, Phillips HS, Ferrara N (1993) Inhibition of vascular endothelial growth factor-induced angiogenesis suppresses tumour growth in vivo. Nature 362: 841-844

Leung DW, Cachianes G, Kuang WJ, Goeddel DV, Ferrara N (1989) Vascular endothelial growth factor is a secreted angiogenic mitogen. Science 246: $1306-1309$

Lin P, Sankar S, Shan S, Dewhirst MW, Polverini PJ, Quinn TQ, Peters KG (1998) Inhibition of tumor growth by targeting tumor endothelium using a soluble vascular endothelial growth factor receptor. Cell Growth Differ 9: $49-58$

Maeda K, Chung YS, Ogawa Y, Takatsuka S, Kang SM, Ogawa M, Sawada T, Sowa M (1996) Prognostic value of vascular endothelial growth factor expression in gastric carcinoma. Cancer 77: 858-863

Masood R, Cai J, Zheng T, Smith DL, Naidu Y, Gill PS (1997) Vascular endothelial growth factor/vascular permeability factor is an autocrine growth factor for AIDS-Kaposi sarcoma. Proc Natl Acad Sci USA 94: 979-984

Masood R, Cai J, Zheng T, Smith DL, Hinton DR, Gill PS (2001) Vascular endothelial growth factor (VEGF) is an autocrine growth factor for VEGF receptor-positive human tumors. Blood 98(Suppl 6): 1904-1913

McLaughlin JK, Lipworth L (2000) Epidemiologic aspects of renal cell cancer. Semin Oncol 27: 115-123

Mercola D, Cohen JS (1995) Antisense approaches to cancer gene therapy. Cancer Gene Ther 2: 47-59

Mordenti J, Thomsen K, Licko V, Chen H, Meng YG, Ferrara N (1999) Efficacy and concentration-response of murine anti-VEGF monoclonal antibody in tumor-bearing mice and extrapolation to humans. Toxicol Pathol 27: 14-21

Nakashima T, Hudson JM, Clayman GL (2000) Antisense inhibition of vascular endothelial growth factor in human head and neck squamous cell carcinoma. Head Neck 22: 483-488

Nguyen JT, Wu P, Clouse ME, Hlatky L, Terwilliger EF (1998) Adeno-associated virus-mediated delivery of antiangiogenic factors as an antitumor strategy. Cancer Res 58: 5673-5677

O’Reilly MS, Boehm T, Shing Y, Fukai N, Vasios G, Lane WS, Flynn E, Birkhead JR, Olsen BR, Folkman J (1997) Endostatin: an endogenous inhibitor of angiogenesis and tumor growth. Cell 88: 277-285

O’Reilly MS, Holmgren L, Shing Y, Chen C, Rosenthal RA, Cao Y, Moses M, Lane WS, Sage EH, Folkman J (1994a) Angiostatin: a circulating endothelial cell inhibitor that suppresses angiogenesis and tumor growth. Cold Spring Harb Symp Quant Biol 59: $471-482$

O’Reilly MS, Holmgren L, Shing Y, Chen C, Rosenthal RA, Moses M, Lane WS, Cao Y, Sage EH, Folkman J (1994b) Angiostatin: a novel angiogenesis inhibitor that mediates the suppression of metastases by a Lewis lung carcinoma. Cell 79: $315-328$

Paradis V, Lagha NB, Zeimoura L, Blanchet P, Eschwege P, Ba N, Benoit G, Jardin A, Bedossa P (2000) Expression of vascular endothelial growth factor in renal cell carcinomas. Virchows Arch 436: 351 - 356

Perletti G, Concari P, Giardini R, Marras E, Piccinini F, Folkman J, Chen L (2000) Antitumor activity of endostatin against carcinogen-induced rat primary mammary tumors. Cancer Res 60: 1793-1796

Phillips MI, Zhang YC (2000) Basic principles of using antisense oligonucleotides in vivo. Methods Enzymol 313: 46-56 
Plate KH, Breier G, Weich HA, Risau W (1992) Vascular endothelial growth factor is a potential tumour angiogenesis factor in human gliomas in vivo. Nature 359: $845-848$

Risau W (1997) Mechanisms of angiogenesis. Nature 386: 671-674

Saleh M, Stacker SA, Wilks AF (1996) Inhibition of growth of C6 glioma cells in vivo by expression of antisense vascular endothelial growth factor sequence. Cancer Res 56: $393-401$

Sato K, Terada K, Sugiyama T, Takahashi S, Saito M, Moriyama M, Kakinuma H, Suzuki Y, Kato M, Kato T (1994) Frequent overexpression of vascular endothelial growth factor gene in human renal cell carcinoma. Tohoku J Exp Med 173: 355 - 360

Sato K, Tsuchiya N, Sasaki R, Shimoda N, Satoh S, Ogawa O, Kato T (1999) Increased serum levels of vascular endothelial growth factor in patients with renal cell carcinoma. Jpn J Cancer Res 90: 874-879

Sidky YA, Auerbach R (1976) Lymphocyte-induced angiogenesis in tumorbearing mice. Science 192: $1237-1238$

Smyth AP, Rook SL, Detmar M, Robinson GS (1997) Antisense oligonucleotides inhibit vascular endothelial growth factor/vascular permeability factor expression in normal human epidermal keratinocytes. J Invest Dermatol 108: $523-526$

Soker S, Gollamudi-Payne S, Fidder H, Charmahelli H, Klagsbrun M (1997) Inhibition of vascular endothelial growth factor (VEGF)-induced endothelial cell proliferation by a peptide corresponding to the exon 7- encoded domain of VEGF165. J Biol Chem 272: $31582-31588$

Stein CA, Cheng YC (1993) Antisense oligonucleotides as therapeutic agents - is the bullet really magical?. Science 261: 1004-1012

Takahashi A, Sasaki H, Kim SJ, Tobisu K, Kakizoe T, Tsukamoto T, Kumamoto Y, Sugimura T, Terada M (1994) Markedly increased amounts of messenger RNAs for vascular endothelial growth factor and placenta growth factor in renal cell carcinoma associated with angiogenesis. Cancer Res 54: $4233-4237$
Tang F, Hughes JA (1999) Synthesis of a single-tailed cationic lipid and investigation of its transfection. J Controlled Release 62: 345-358

Toi M, Hoshina S, Takayanagi T, Tominaga T (1994) Association of vascular endothelial growth factor expression with tumor angiogenesis and with early relapse in primary breast cancer. Jpn J Cancer Res 85: 1045-1049

Tomisawa M, Tokunaga T, Oshika Y, Tsuchida T, Fukushima Y, Sato H, Kijima H, Yamazaki H, Ueyama Y, Tamaoki N, Nakamura M (1999) Expression pattern of vascular endothelial growth factor isoform is closely correlated with tumour stage and vascularisation in renal cell carcinoma. Eur J Cancer 35: $133-137$

Wang Y, Becker D (1997) Antisense targeting of basic fibroblast growth factor and fibroblast growth factor receptor-1 in human melanomas blocks intratumoral angiogenesis and tumor growth. Nat Med 3: 887-893

Weidner N, Semple JP, Welch WR, Folkman J (1991) Tumor angiogenesis and metastasis - correlation in invasive breast carcinoma. $N$ Engl J Med 324(1): $1-8$

Workman P, Twentyman P, Balkwill F, Balmain A, Chaplin D, Double J, Embleton J, Newell D, Raymond R, Stables J, Stephens T, Wallace J (1998) United Kindom Co-ordinating Committee on Cancer Research (UKCCCR) Guidelines for the Welfare of Animals in Experimental Neoplasia (Second Edition). Br J Cancer 77: 1-10

Yoshino S, Kato M, Okada K (2000) Clinical significance of angiogenesis, proliferation and apoptosis in renal cell carcinoma. Anticancer Res 20 $591-594$ 